\title{
Pemberdayaan Masyarakat di Wisata Edukasi Imah Noong Kampung Areng Kecamatan Lembang Kabupaten Bandung Barat
}

\author{
Seno Hardianto, Titing Kartika, Rieke Sri Rizki Asti Karini \\ STIEPAR YAPARI AKTRIPA Bandung \\ senohardi@ outlook.com, nengtiting_kartika@yahoo.co.id, rsrak17@yahoo.com
}

\begin{abstract}
Community empowerment is the effort to create and improve the capacity of the community both individually and groups in solving various problems related to efforts for improve the quality of life, independence and prosperity. Community empowerment can be done through the various ways and one of them through the growth and development. This research was conducted in Wisata Edukasi Imah Noong, Kampung Areng Desa Wangunsari Kecamatan Lembang Kabupaten Bandung Barat. The method of this research is descriptive research method with qualitative approach. Data collection method used is field observation, interview and documentation. Primary data source obtained from purposive sampling. Then from the results of this research be obtained a conclusion of action or activities of the community in the implementation of the concept of community empowerment approach through development of tourism, namely strengthening the capacity and role of society, strengthening access and business opportunities, and strengthening of tourism awareness.
\end{abstract}

Keywords_community empowerment; public business opportunity; tourism awareness

Abstrak- Pemberdayaan masyarakat adalah upaya menciptakan dan meningkatkan kapasitas masyarakat baik secara individu maupun kelompok dalam memecahkan berbagai persoalan terkait upaya peningkatan kualitas hidup, kemandirian, dan kesejahteraannya. Pemberdayaan masyarakat dapat dilakukan melalui beragam cara dan salah satunya melalui pembangunan dan pengembangan pariwisata. Penelitian ini dilakukan di Wisata Edukasi Imah Noong, Kampung Areng Desa Wangunsari Kecamatan Lembang Kabupaten Bandung Barat. Adapun metode penelitian yang digunakan adalah metode penelitian deskriptif dengan pendekatan kualitatif. Teknik pengumpulan data dilakukan dengan cara observasi lapangan, wawancara dan dokumentasi. Sumber data primer diperoleh dari purposive sampling. Kemudian dari hasil penelitian ini didapatkan suatu kesimpulan berupa kegiatan atau aktivitas masyarakat dalam implementasi dari konsep pendekatan pemberdayaan masyarakat melalui pembangunan kepariwisataan, yaitu penguatan kapasitas dan peran masyarakat, penguatan akses dan kesempatan berusaha masyarakat, serta penguatan sadar wisata.

Kata kunci-pemberdayaan masyarakat; kesempatan usaha masyarakat; sadar wisata

\section{PENDAhUluan}

Untuk mengembangkan potensi pariwisata yang ada di Kabupaten Bandung Barat khususnya Kecamatan Lembang, Pemerintah Daerah serius untuk membangun potensi menjadi suatu atraksi wisata dengan konsep mendidik dan berlandaskan pemberdayaan masyarakat. Sebagaimana tertuang dalam Pasal 8 Peraturan Daerah Kabupaten Bandung Barat Nomor 7 tahun 2013 tentang Penyelenggaraan Kepariwisataan Daerah Bagian Ketiga tentang Pembangunan Destinasi Pariwisata yaitu, pembangunan destinasi pariwisata meliputi pemberdayaan masyarakat, pembangunan daya tarik wisata, pembangunan prasarana dan penyediaan fasilitas umum serta pembangunan fasilitas pariwisata.
Pembangunan serta pengembangan konsep wisata yang mendidik ini membuat Lembang menjadi salah satu daerah yang mengembangkan salah satu wisata minat khusus yaitu wisata edukasi yang berlandaskan pemberdayaan masyarakat sekitar. Dari sekian banyak wisata minat khusus edukasi yang terdapat di Lembang, terdapat sebuah observatorium atau tempat mengamati benda langit pribadi yang mengusung konsep wisata edukasi adalah Imah Noong.

Imah Noong adalah Observatorium milik pribadi yang terletak di Kampung Areng Desa Wangunsari Kecamatan Lembang Kabupaten Bandung Barat. Imah Noong merupakan sebuah observatorium astronomi dan planetarium dengan konsep wisata edukasi. Pada awalnya Imah Noong dibangun hanya untuk pengamatan 
benda langit dan bersifat pribadi. Dikarenakan banyaknya peminat maka tempat ini dibuka untuk wisatawan yang ingin mempelajari ilmu Astronomi. Imah Noong ini memiliki keunikan ketika atap imah atau sebuah ruangan yang terdapat teropong di dalamnya dapat digeser sehingga bagian dalam Imah Noong yang berisi teleskop bisa digunakan untuk melihat benda langit. Pembangunan Wisata Edukasi Imah Noong ini sejalan dengan Perda Kabupaten Bandung Barat yang memiliki visi menjadi pusat sarana wisata edukasi yang menyatu dengan masyarakat menuju kampung yang berkualitas, ramah lingkungan, berbudaya, maju dan mandiri.

Pada kenyataannya wisata edukasi Imah Noong ini belum mendapatkan pengakuan dan pembinaan, baik dari pihak Dinas Kebudayaan dan Pariwisata (DISBUDPAR) Kabupaten Bandung Barat maupun Badan Perencanaan dan Pembangunan Daerah Pemerintah (BAPPEDA) Kabupaten Bandung Barat. Tapi baru sebatas dukungan dari Kepala Camat Kecamatan Lembang. Oleh karena belum adanya bantuan lebih jauh dari pihak Pemerintah Kabupaten Bandung Barat, sehingga pengelolaan wisata edukasi Imah Noong ini masih menggunakan dana dari pihak pribadi dan bantuan dari instansi lainnya.

Keberadaan Imah Noong di Kampung Areng sebagai sebuah daya tarik berbasis wisata edukasi ini tidak bisa terlepas dari peranan masyarakat sekitar Imah Noong. Karena sesuai dengan pendirian Wisata Edukasi Imah Noong yang memiliki misi yaitu pemberdayaan masyarakat melalui eduwisata, melestarikan seni dan budaya tradisional serta meningkatkan Sumber Daya Manusia dan Sumber Daya Alam lebih maju. Hal ini sejalan dengan penjelasan dari Sunaryo (2013:221), bahwa

"Upaya pemberdayaan masyarakat melalui kepariwisataan pada prinsipnya harus senantiasa diarahkan pada pencapaian empat sasaran utama", yaitu:

1. Peningkatan kapasitas, peran dan inisiatif masyarakat sebagai subyek atau pelaku penting dalam pembangunan kepariwisataan;

2. Peningkatan posisi dan kualitas keterlibatan/partisipasi masyarakat dalam pengembangan kepariwisataan;

3. Peningkatan nilai manfaat posistif pembangunan pariwisata bagi kesejahteraan sosial, ekonomi dan budaya masyarakat dan;

4. Peningkatan kemampuan masyarakat dalam melakukan perjalanan wisata.
Masyarakat sekitar Kampung Areng sebenarnya sudah ikut mendorong berkembangnya wisata edukasi Imah Noong. Hal ini terlihat dari kegiatan masyarakat sekitar Imah Noong yang ikut berpartisipasi dalam kegiatan pariwisata di Imah Noong. Akan tetapi, tidak sedikit masyarakat yang tetap berprofesi sebagai buruh serabutan dan bahkan banyak dari anak mereka putus sekolah hanya untuk membantu orang tuanya bekerja. Sehingga kegiatan pemberdayaan masyarakat dengan hadirnya Wisata Edukasi Imah Noong di Kampung Areng ini masih kurang dirasakan manfaatnya oleh masyarakat sekitar maupun oleh pengelola Imah Noong. Dengan mempertimbangkan segala potensi dan serangkaian aktivitas yang berkaitan dengan pentingnya peranan dan pemberdayaan masyarakat terhadap pembangunan dan pengembangan Imah Noong sebagai daya tarik wisata berbasis Edukasi di Kampung Areng. Maka untuk itu penulis tertarik untuk melakukan penelitian ini.

\section{KAJIAN PUSTAKA}

\section{A. Pariwisata}

Dalam Undang-Undang Nomor 10 Tahun 2009 tentang Kepariwisataan, diberikan batasan pengertian wisata sebagai, kegiatan perjalanan yang dilakukan oleh seseorang atau sekelompok orang dengan mengunjungi tempat tertentu untuk tujuan rekreasi, pengembangan pribadi, atau mempelajari keunikan daya tarik wisata yang dikunjungi dalam jangka waktu sementara. Secara lebih luas dijelaskan bahwa pariwisata adalah berbagai macam kegiatan wisata dan didukung berbagai fasilitas serta layanan yang disediakan oleh masyarakat, pengusaha dan pemerintah.

Pariwisata dapat didefinisikan sebagai proses dan hasil yang timbul dari hubungan interaksi antara wisatawan, pemasok pariwisata, pemerintah tuan rumah daerah tujuan wisata, masyarakat tuan rumah daerah tujuan wisata, dan lingkungan sekitar tujuan wisata yang terlibat dalam menarik dan menerima wisatawan. Hal ini sesuai dengan pernyataan Ritchie dan Goeldner (2009:6):

Tourism may be defined as the processes, activities, and outcomes arising from the relationships and the interactions among tourists, tourism suppliers, host governments, host communities, and surrounding environments that are involved in the attracting and hosting of visitors.

\section{B. Daya Tarik Wisata}

Dalam Undang - Undang Nomor 10 Tahun 2009 tentang Kepariwisataan, daya tarik wisata 
adalah segala sesuatu yang memiliki keunikan, keindahan, dan nilai yang berupa keanekaragaman kekayaan alam, budaya, dan hasil buatan manusia yang menjadi sasaran atau tujuan kunjungan wisatawan. Hadiwijoyo (2012:49) menyatakan bahwa daya tarik wisata merupakan suatu bentuk dan fasilitas yang berhubung yang dapat menarik minat wisatawan atau pengunjung untuk datang ke suatu daerah atau tempat tertentu. Dijelaskan juga bahwa daya tarik wisata dapat dibedakan menjadi 3 yaitu:

\section{Daya tarik wisata alam}

Yaitu sumber daya alam yang berpotensi serta memiliki daya tarik bagi pengunjung baik dalam keadaan alami maupun setelah ada usaha budi daya.

2. Daya tarik wisata sosial budaya

Keadaan sosial dan budaya dapat dimanfaatkan dan dikembangkan sebagai daya tarik wisata meliputi museum, peninggalan sejarah, situs arkeologi, upacara adat, kerajinan, dan seni pertunjukan

3. Daya tarik wisata minat khusus Yaitu jenis wisata yang mengutamakan wisatawan dengan minat khusus

Apabila dilihat dari jenis atraksi wisata maka Wisata Edukasi Imah Noong termasuk ke dalam atraksi wisata khusus yang mengusung konsep dan tema wisata edukasi yang dimilikinya.

\section{Daya Tarik Minat Khusus}

Menurut Simanjuntak (2015:165) bahwa daya tarik wisata minat khusus "umumnya berdasarkan pada sumber daya yang dapat menimbulkan rasa senang, indah, nyaman dan bersih. Selain itu, adanya ciri khusus/spesifikasi yang bersifat langka, adanya sarana/prasarana penunjang untuk melayani para wisatawan yang hadir, mempunyai daya tarik yang tinggi karena keindahan alam atau memiliki suatu nilai khusus dalam bentuk budaya juga tergolong daya tarik wisata minat khusus. Pemanfaatan potensi kekhasan objek menjadikan daya tarik tersendiri untuk wisata minat khusus, seperti wisata konvensi, wisata politik, wisata pilgrim, wisata pertanian, wisata intelektual, wisata kuliner, wisata pasar, dan lain-lain." Wisata minat khusus tersebut adalah wisata edukasi yang merupakan salah satu bagian wisata minat khusus yang merupakan konsep dan tema utama dari Imah Noong Lembang.

\section{Wisata Edukasi}

Secara etimologis, menurut Suroso (2004:5) kata edukasi ini berasal dari kata lain yaitu educare yang artinya memunculkan atau membawa. Dalam pengertian secara luas edukasi adalah setiap tindakan atau pengalaman yang memiliki efek normatif pada karakter, pikiran atau kemampuan fisik dalam individu. Saat ini banyak persepsi mengenai Educational Tourism yang bermunculan di Indonesia, hal ini dikarenakan pemerintah Indonesia belum menetapkan Undang - Undang yang mengatur kegiatan pariwisata berbasis pendidikan. Akan tetapi, Organisasi Pariwisata Dunia (WTO) menjadikan wisata edukasi menjadi suatu bagian yang tidak bisa terpisahkan dari pariwisata.

Pengertian wisata edukasi menurut penjelasan Ritchie (2003:18) adalah,

Tourist activity undertaken by those who are undertaking an overnight vacation and those who are undertaking an excursion form whom education and learning is a primary or secondary part od their trip.This can include general educational tourism and adult study tours, international and domestic university and school students travel, including language school, school excursions and exchange programmes. Educational tourism can be independently or formally organised and can be undertaken in a variety of natural or human made settings.

Dari penjelasan tersebut disimpulkan bahwa wisata edukasi adalah aktivitas pariwisata yang dilakukan oleh wisatawan yang mengambil liburan sehari dan mereka yang melakukan perjalanan untuk pendidikan dan pembelajaran sebagai tujuan utama ataupun kedua. Wisata edukasi dilihat berdasarkan pengaruh lingkungan eksternal yang mempengaruhi penawaran dan permintaan produk daya tarik wisata edukasi untuk memenuhi kebutuhan yang berbeda.

\section{E. Pemberdayaan Masyarakat}

Mardikanto (2015:30) menyatakan bahwa pemberdayaan masyarakat dapat diartikan sebagai upaya peningkatan kemampuan masyarakat (miskin, marjinal, terpinggirkan) untuk menyampaikan pendapat dan atau kebutuhannya, pilihan - pilihannya, berpartisipasi, bernegosiasi, mempengaruhi dan mengelola kelembagaan masyarakatnya secara bertanggung - gugat (accountable) demi perbaikan kehidupannya.

Slamet (dalam Anwas 2013:49) menyatakan bahwa hakikat pemberdayaan adalah bagaimana membuat masyarakat mampu membangun dirinya dan memperbaiki kehidupannya sendiri. Menurut Peraturan Menteri Kebudayaan dan Pariwisata Nomor KM 18/HM 001/MKP/2011 tentang Pedoman 
Program Nasional Pemberdayaan Masyarakat (PNPM) Mandiri Pariwisata, bahwa "Pemberdayaan masyarakat adalah menciptakan/meningkatkan kapasitas masyarakat baik secara individu maupun kelompok dalam memecahkan berbagai persoalan terkait upaya peningkatan kualitas hidup, kemandirian, dan kesejahteraannya."

Lebih lanjut Mardikanto (2015:105) menyatakan bahwa pemberdayaan memiliki prinsip - prinsip :

1. Mengerjakan, artinya kegiatan pemberdayaan masyarakat harus sebanyak mungkin melibatkan masyarakat untuk mengerjakan/menerapkan sesuatu. Karena melalui "mengerjakan" mereka akan mengalami proses belajar yang akan terus diingat.

2. Akibat, artinya kegiatan pemberdayaan harus memberikan akibat atau pengaruh yang baik atau bermanfaat.

3. Asosiasi, artinya setiap kegiatan pemberdayaan harus dikaitkan dengan kegiatan lainnya, sebab, setiap orang cenderung untuk mengaitkan/ menghubungkan kegiatannya dengan kegiatan/peristiwa yang lainnya."

Menurut Suharto (2014:67), penerapan pendekatan pemberdayaan dapat dilakukan melalui 5P yaitu:

1. Pemungkinan. Menciptakan suasana atau iklim yang memungkinkan potensi masyarakat berkembang secara optimal. Pemberdayaan harus mampu membebaskan masyarakat dari sekarat-sekarat kultural dan struktur yang menghambat.

2. Penguatan. Memperkuat pengetahuan dan kemampuan yang dimiliki masyarakat dalam memecahkan masalah dan memenuhi kebutuhannya. Pemberdayaan harus mampu menumbuhkembangkan segenap kemampuan dan kepercayaan diri masyarakat yang menunjang kemandirian mereka.

3. Perlindungan. Melindungi masyarakat terutama kelompok-kelompok lemah agar tidak tertindas oleh kelompok kuat, menghindari terjadinya persaingan yang tidak seimbang antara yang kuat dan lemah, dan mencegah terjadinya eksploitasi kelompok kuat terhadap kelompok lemah. Pemberdayaan harus diarahkan kepada penghapusan segala jenis diskriminasi dan dominasi yang tidak menguntungkan rakyat kecil.

4. Penyokongan. Memberikan bimbingan dan dukungan agar masyarakat mampu menjalankan perannya dan tugas - tugas kehidupannya. Pemberdayaan harus mampu menyokong masyarakat agar tidak terjatuh ke dalam keadaan dan posisi yang semakin lemah dan terpinggirkan.

Pemeliharaan. Memelihara kondisi yang kondusif agar tetap terjadi keseimbangan distribusi kekuasaan antara berbagai kelompok dalam masyarakat. Pemberdayaan harus mampu menjamin keselarasan dan keseimbangan yang memungkinkan setiap orang memperoleh kesempatan berusaha."

Dalam kepariwisataan, kita mengenal adanya konsep pariwisata berbasis masyarakat atau Community Based Tourism (CBT) yang merupakan salah satu strategi dari usaha pemberdayaan masyarakat di Indonesia. Menurut Ardika (2007:8) menyatakan bahwa konsep ini mengikuti keputusan Pemerintah Indonesia melalui Menteri Kebudayaan dan Pariwisata yang telah mencanangkan paradigma baru dalam pengembangan kepariwisataan, yakni Pariwisata Kerakyatan berkesinambungan yang kini kita kenal dengan Pariwisata Berbasis Masyarakat.

$$
\text { Selanjutnya, Sunaryo (2013:221) }
$$
menyatakan bahwa upaya pemberdayaan masyarakat melalui kepariwisataan pada prinsipnya harus senantiasa diarahkan pada pencapaian empat sasaran utama, yaitu:

1. Peningkatan kapasitas, peran dan inisiatif masyarakat sebagai subyek atau pelaku penting dalam pembangunan kepariwisataan;

2. Peningkatan posisi dan kualitas keterlibatan/partisipasi masyarakat dalam pengembangan kepariwisataan;

3. Peningkatan nilai manfaat posistif pembangunan pariwisata bagi kesejahteraan sosial, ekonomi dan budaya masyarakat dan;

4. Peningkatan kemampuan masyarakat dalam melakukan perjalanan wisata."

Dengan mengacu kepada ke-4 sasaran di atas maka kerangka pemberdayaan masyarakat melalui pembangunan kepariwisataan. Sasaran tersebut lebih lanjut, Sunaryo (2013:222) harus bermuara pada tiga aspek sebagai berikut :

1. Penguatan kapasitas dan peran masyarakat, terkait dengan upaya meningkatkan peran dan kapasitas masyarakat untuk turut aktif dalam kegiatan dan proses pembangunan kepariwisataan.

2. Penguatan akses dan kesempatan berusaha masyarakat, terkait dengan upaya meningkatkan nilai manfaat ekonomi bagi masyarakat dari usaha kepariwisataan.

3. Penguatan sadar wisata, terkait dengan upaya meningkatkan kesadaran dan peran masyarakat dalam mendukung 
pengembangan kepariwisataan serta dapat menjadi pelaku usaha, pekerja maupun sebagai wisatawan."

F. Tujuan Pemberdayaan Masyarakat

Menurut Mardikanto (2015:109) tujuan pemberdayaan masyarakat meliputi beragam upaya perbaikan sebagai berikut:

1. Better Education - Perbaikan Pendidikan

2. Better Accessibility - Perbaikan aksesibilitasnya, utamanya tentang aksesibilitas dengan sumber informasi/ inovasi, sumber pembiayaan, penyedia produk dan peralatan, lembaga pemasaran

3. Better Action - Perbaikan tindakan

4. Better Institution - Perbaikan kelembagaan

5. Better Business - Perbaikan usaha

6. Better Income - Perbaikan pendapatan

7. Better Environment - Perbaikan lingkungan

8. Better Living - Perbaikan kehidupan

9. Better Community - Perbaikan masyarakat" Dalam program pemberdayaan masyarakat melalui kepariwisataan memiliki beberapa sasaran atau tujuan sebagaimana dijelaskan Sunaryo (2013:220), bahwa

1. Mendorong masyarakat di destinasi untuk mengenali dan menyadari masalah kepariwisataan yang dihadapinya serta secara bersama-sama dan mandiri memecahkan masalah tersebut;

2. Memperkuat atau membangun organisasi atau kelompok di bidang kepariwisataan sebagai wadah untuk kebersamaan (kerja sama), keswadayaan, dan pertanggung jawaban;

3. Memperkuat bargaining position (posisi tawar) kelompok kepariwisataan itu di hadapan pemerintah, elite, maupun pemilik modal;

4. Meningkatkan partisipasi masyarakat dalam berbagai urusan kepariwisataan melalui wadah kelompok/organisasi sosial tersebut;

5. Meningkatkan pengetahuan dan keterampilan sumber daya manusia pariwisata yang ada melalui wadah kelompoknya;

6. Membangun tata kelola kepariwisataan yang baik dan membuka akses yang luas terhadap keadilan;

7. Memperkuat posisi masyarakat setempat dalam usaha kepariwisataan;

8. Memperkuat kapasitas organisasi masyarakat dibidang kepariwisataan;

9. Meningkatkan jangkauan informasi masyarakat yang menyangkut kehidupan mereka;

10. Meningkatkan kemandirian masyarakat pariwisata melalui kelompok dalam hal permodalan, membuat keputusan dan menghidupi kelompok;

11. Mendorong peningkatan kemakmuran ekonomi, kesetaraan politik, dan kesejahteraan sosial masyarakat melalui kepariwisataan."

\section{G. Pengembangan Sadar Wisata}

Masyarakat dituntut peduli dan sadar akan potensi yang dimilikinya karena pihak masyarakat merupakan bagian penting dalam proses pembangunan kepariwisataan yang memiliki peran strategis. Peranan tersebut tidak hanya sebagai penerima manfaat, namun sekaligus harus mampu menjadi pelaku yang mendorong keberhasilan pengembangan kepariwisataan di wilayahnya masing-masing. konteks pemberdayaan masyarakat untuk pengembangan kepariwisataan diperlukan juga konsep "Sadar Wisata". Pada intinya memiliki dua sasaran utama seperti yang dikemukakan oleh Sunaryo (2013:222) bahwa

1. Mendorong masyarakat untuk dapat menciptakan iklim yang kondusif bagi tumbuh dan berkembangnya kegiatan kepariwisataan yang berada diwilayahnya. (masyarakat sebagai tuan rumah)

2. Mendorong masyarakat untuk dapat menjadi pelaku dan pekerja di sektor kepariwisataan yang ada di wilayahnya baik secara langsung maupun tidak langsung serta mendorong masyarakat itu sendiri menjadi wisatawan atau pihak yang melakukan perjalanan wisata ke suatu destinasi wisata yang lain sebagai wisatawan khususnya dalam lingkup wilayah nusantara (masyarakat sebagai wisatawan/tamu)"

Lebih lanjut Sunaryo (2013:222) menyatakan bahwa partisipasi dan dukungan masyarakat merupakan aspek penting agar siap untuk berperan sebagai tuan rumah (host) dan memahami serta bersedia untuk mewujudkan SAPTA PESONA dilingkungannya. Sapta Pesona merupakan jabaran konsep "Sadar Wisata" yang terkait dengan lingkungan dan suasana kondusif yang mampu mendorong tumbuh dan berkembangnya industri pariwisata, melalui perwujudan unsur aman, tertib, bersih, sejuk, indah, ramah, kenangan.

\section{Metode Penelitian}

Metode yang digunakan adalah metode penelitian deskriptif melalui pendekatan kualitatif. Menurut Creswell (1998) dikutip dari Utama \& Mahadewi (2012:119) pendekatan kualitatif adalah suatu proses penelitian dan pemahaman yang berdasarkan pada metodologi 
yang menyelidiki suatu fenomena sosial dan masalah manusia. Pada pendekatan ini, peneliti membuat suatu gambaran kompleks, meneliti kata-kata, laporan terinci dari pandangan responden, dan melakukan studi pada situasi yang alami. Penggunaan metode ini dirasa akan memberikan hasil situasional dan gambaran kompleks sesuai dengan aktivitas terkait pemberdayaan masyarakat yang ada di Wisata Edukasi Imah Noong Kampung Areng Lembang Kabupaten Bandung Barat.

\section{A. Teknik Pengumpulan Data}

Teknik pengumpulan data yang digunakan oleh penulis dalam melakukan penelitian ini adalah sebagai berikut:

1. Observasi

Observasi yang digunakan adalah observasi partisipatif. Menurut Sugiyono (2014:64) penulis terlibat dengan kegiatan sehari-hari orang yang sedang diamati atau yang digunakan sebagai sumber data penelitian.

2. Wawancara

Wawancara menurut Esterberg (dalam Sugiyono,2014:72) merupakan pertemuan dua orang untuk bertukar informasi dan ide melalui tanya jawab, sehingga dapat dikonstruksikan makna dalam suatu topik tertentu. Dalam penelitian ini, digunakan wawancara tak berstruktur (unstructured interview) "dimana wawancara dilakukan oleh peneliti secara bebas dan hanya menggunakan garis-garis besar dari permasalahan yang akan ditanyakan."

Penulis menggunakan narasumber pihak pengelola Imah Noong dan masyarakat sekitar Imah Noong yaitu di RW 11 dan RW 12 Kampung Areng. Kemudian Pemerintah atau Dinas terkait seperti Kantor Desa Wangunsari, Lembaga Pemberdayaan Masyarakat Kecamatan Lembang Kabupaten Bandung Barat, Badan Perencanaan Penelitian Pembangunan Daerah (BAPPEDA) Kabupaten Bandung Barat, Dinas Kebudayaan dan Pariwisata Kabupaten Bandung Barat serta Badan Pemberdayaan Masyarakat Daerah (BPMD) Kabupaten Bandung Barat.

3. Dokumentasi

Dokumen merupakan catatan peristiwa yang sudah berlalu. Menurut Sugiyono (2014:228) dokumen bisa berbentuk tulisan, gambar, atau karya-karya monumental dari seseorang. Dokumen yang berbentuk gambar, misalnya foto, gambar hidup, sketsa dan lain-lain. Studi dokumen merupakan pelengkap dari penggunaan metode observasi dan penelitian kualitatif. Dalam penelitian ini, digunakan kamera digital dan alat perekam suara sebagai sarana dokumentasi.

\section{B. Sampel}

Menurut Sugiyono (2014:49) populasi adalah wilayah generalisasi yang terdiri atas obyek atau subyek yang mempunyai kualitas dan karakteristik tertentu yang ditetapkan oleh peneliti untuk dipelajari dan kemudian ditarik kesimpulannya, sementara sampel adalah bagian dari jumlah dan karakteristik yang dimiliki oleh populasi tersebut. Dikarenakan lokasi Imah Noong yang berada di Kampung Areng, Desa Wangunsari, Kecamatan Lembang, maka populasi berdasarkan data dari Kantor Desa Wangunsari (2017) menyebutkan bahwa jumlah populasi masyarakat Kampung Areng berjumlah 3.894 jiwa dan jumlah pengelola Wisata Edukasi Imah Noong sebanyak 8 orang.

Teknik pengambilan sampel yang digunakan dalam penelitian ini adalah sampling insidental dan purposive sampling Sugiyono (2014:54) bahwa sampling insidental merupakan teknik penentuan sampel berdasarkan kebetulan, yaitu siapa saja yang secara kebetulan/insidental bertemu dengan penulis dapat digunakan sebagai sampel, bila dipandang orang yang kebetulan ditemui cocok sebagai sumber data. Purposive sampling yaitu metode penetapan sampel dengan pertimbangan tertentu. Pertimbangan tertentu ini adalah menentukan orang yang dianggap paling tahu dan dapat memberikan data lebih lengkap dalam mengembangkan sumber daya manusianya, sehingga akan memudahkan penulis untuk menjelajahi objek/situasi sosial yang diteliti.

TABel 1. Sumber Data Masyarakat KAMPUng ARENG

\begin{tabular}{|c|c|c|}
\hline No & Sumber Data & Informasi \\
\hline 1 & $\begin{array}{l}\text { Ibu Nuri } \\
\text { (Pemilik } \\
\text { Peternakan } \\
\text { Sapi Perah) }\end{array}$ & $\begin{array}{ll}\text { - } & \text { Pemberdayaan } \\
\text { masyarakat } \\
\text { - } & \text { Program pemberdayaan } \\
\text { melalui kegiatan } \\
\text { masyarakat sekitar } \\
\text { - } \quad \text { Dampak hadirnya Imah } \\
\text { Noong } \\
\text { Kontribusi masyarakat } \\
\text { - } \quad \text { Perhadap Imah Noong } \\
\text { Wisata }\end{array}$ \\
\hline 2 & $\begin{array}{l}\text { Siti Nurjanah } \\
\text { (Ketua } \\
\text { Karang } \\
\text { Taruna RW } \\
\text { 12) }\end{array}$ & $\begin{array}{ll}\text { - } & \text { Pemberdayaan } \\
\text { masyarakat melalui } \\
\text { Karang Taruna RW.12 } \\
\text { - } \quad \text { Dampak hadirnya Imah } \\
\text { Noong }\end{array}$ \\
\hline
\end{tabular}




\begin{tabular}{|c|c|c|}
\hline No & Sumber Data & Informasi \\
\hline 3 & $\begin{array}{l}\text { Ibu Elis Cucu } \\
\text { (Tokoh } \\
\text { masyarakat) }\end{array}$ & $\begin{array}{ll}\text { - } & \text { Kontribusi masyarakat } \\
\text { - } & \text { Perhadap Imah Noong } \\
\text { Wisata } & \text { Program Karang } \\
\text { - } & \text { Taruna untuk Imah } \\
\text { Noong } \\
\text { - } \quad \text { Kegiatan } \\
\text { pemberdayaan di } \\
\text { Kampung Areng } \\
\text { Dampak hadirnya Imah } \\
\text { - } \quad \text { Koong } \\
\text { Kontribusi masyarakat } \\
\text { terhadap Imah Noong } \\
\text { Penyuluhan Sadar } \\
\text { Wisata } \\
\text { Tanggapan masyarakat } \\
\text { terhadap pemberdayaan } \\
\text { masyarakat }\end{array}$ \\
\hline TAF & L 2. SUMBER D & TAA PENGELOLA IMAH NOONG \\
\hline No & $\begin{array}{l}\text { Sumber } \\
\text { Data }\end{array}$ & Informasi \\
\hline 1 & $\begin{array}{l}\text { Bapak } \\
\text { Hendro } \\
\text { Setyanto, } \\
\text { M.Si. } \\
\text { (Pemilik } \\
\text { Imah } \\
\text { Noong) }\end{array}$ & 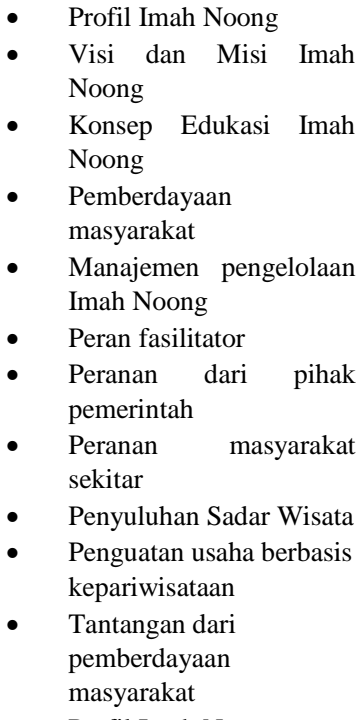 \\
\hline 2 & $\begin{array}{l}\text { Bapak Fahri } \\
\text { Ahmad, } \\
\text { M.Si. } \\
\text { (Pengelola } \\
\text { Imah } \\
\text { Noong) }\end{array}$ & $\begin{array}{ll}\text { - } & \text { Profil Imah Noong } \\
& \text { Konsep Edukasi Imah } \\
& \text { Noong } \\
\text { - } & \text { Pemberdayaan } \\
& \text { masyarakat } \\
\text { - } & \text { Manajemen pengelolaan } \\
& \text { Imah Noong } \\
\text { - } \quad \text { Peran fasilitator } \\
\text { - } \quad \text { Peranan masyarakat } \\
\text { - } \quad \text { Pekitar } \quad \text { Penyuluhan Sadar Wisata } \\
\text { - } \quad \text { kepariwan usaha berbasis } \\
\text { Tantangan dari } \\
\text { pemberdayaan } \\
\text { masyarakat }\end{array}$ \\
\hline 3 & $\begin{array}{l}\text { Ibu Eva } \\
\text { Cintawati }\end{array}$ & $\begin{array}{l}\text { Pemberdayaan } \\
\text { masyarakat }\end{array}$ \\
\hline
\end{tabular}

\begin{tabular}{|c|c|c|}
\hline No & $\begin{array}{c}\text { Sumber } \\
\text { Data }\end{array}$ & Informasi \\
\hline & $\begin{array}{l}\text { (Pengelola } \\
\text { Imah } \\
\text { Noong) }\end{array}$ & $\begin{array}{ll}\text { - } & \text { Peranan masyarakat } \\
& \text { sekitar } \\
\text { - } & \text { Penyuluhan Sadar Wisata } \\
\text { - } & \text { Pengaruh masyarakat } \\
& \text { terhadap Imah Noong } \\
\text { - } & \text { Tanggapan masyarakat } \\
& \text { terhadap pemberdayaan } \\
\text { masyarakat }\end{array}$ \\
\hline
\end{tabular}

TABel 3. Sumber DAta PeMERINTAH

\begin{tabular}{|c|c|c|}
\hline No & Sumber Data & Informasi \\
\hline 1 & $\begin{array}{l}\text { Bapak Dede } \\
\text { Mahdar } \\
\text { (Kabag } \\
\text { Kesejahteraan } \\
\text { Desa } \\
\text { Wangunsari) }\end{array}$ & $\begin{array}{ll}\text { - } & \text { Profil Desa } \\
\text { - } & \text { Mata Pencaharian } \\
\text { masyarakat } \\
\text { - } & \text { Pemberdayaan } \\
\text { masyarakat } \\
\text { - } \\
\text { Rencana } \\
\text { - } \quad \text { Pengembangan Desa } \\
\text { Pelatihan dan } \\
\text { Penyuluhan Sadar } \\
\text { Wisata }\end{array}$ \\
\hline 2 & $\begin{array}{l}\text { Bapak Ari } \\
\text { Wibisana, S.IP. } \\
\text { (KASUBBID } \\
\text { Pertanian, } \\
\text { Pariwisata, } \\
\text { Pertambangan } \\
\text { \& Energi } \\
\text { BAPPEDA } \\
\text { Kabupaten } \\
\text { Bandung Barat) }\end{array}$ & $\begin{array}{ll}\text { - } & \text { Program } \\
\text { Pengembangan } \\
\text { Pariwisata } \\
\text { Penyelenggaraan } \\
\text { Pembangunan } \\
\text { Pariwisata } \\
\text { - } \quad \text { Rencana } \\
\text { Pembangunan } \\
\text { Jangka Pendek } \\
\text { Kabupaten Bandung } \\
\text { Barat } \\
\text { Program } \\
\text { Pemberdayaan } \\
\text { Masyarakat } \\
\text { Pengawasan } \\
\text { Pengembangan } \\
\text { Pariwisata }\end{array}$ \\
\hline 3 & $\begin{array}{l}\text { Ibu Nunung } \\
\text { Nurhasanah, } \\
\text { S.Pt. } \\
\text { (Tenaga Ahli } \\
\text { Badan } \\
\text { Pemberdayaan } \\
\text { Masyarakat } \\
\text { Daerah } \\
\text { Kabupaten } \\
\text { Bandung Barat) }\end{array}$ & $\begin{array}{ll}\text { - } & \text { Pengertian } \\
\text { Pemberdayaan } \\
\text { masyarakat } \\
\text { - } \quad \text { Program } \\
\text { Pemberdayaan } \\
\text { masyarakat } \\
\text { Pemberdayaan } \\
\text { masyarakat melalui } \\
\text { pariwisata } \\
\text { Program khusus } \\
\text { untuk Desa } \\
\text { Wangunsari }\end{array}$ \\
\hline 4 & $\begin{array}{l}\text { Ibu Sri Rahayu, } \\
\text { S.E. } \\
\text { (Tenaga Ahli } \\
\text { Badan } \\
\text { Pemberdayaan } \\
\text { Masyarakat } \\
\text { Kecamatan } \\
\text { Lembang) }\end{array}$ & $\begin{array}{ll}\text { - } & \text { Program } \\
\text { Pemberdayaan } \\
\text { masyarakat } \\
\text { - } \quad \text { Peranan pelaku } \\
\text { wisata dalam } \\
\text { pemberdayaan } \\
\text { - } \\
\text { Pemberdayaan } \\
\text { masyarakat melalui } \\
\text { pariwisata } \\
\text { Program khusus } \\
\text { untuk Desa } \\
\text { Wangunsari }\end{array}$ \\
\hline 5 & $\begin{array}{l}\text { Ibu Cucu } \\
\text { Hertika S.Sos. } \\
\text { (Sekretaris } \\
\text { Dinas }\end{array}$ & $\begin{array}{l}\text { - Statistik wisatawan } \\
\text { Kabupaten Bandung } \\
\text { Barat }\end{array}$ \\
\hline
\end{tabular}




\begin{tabular}{llll}
\hline No & Sumber Data & & \multicolumn{1}{c}{ Informasi } \\
\hline & Pariwisata dan & $\bullet$ & Rencana \\
Kebudayaan & & Pengembangan \\
Kabupaten & & Jangka Pendek \\
Bandung Barat) & $\bullet$ & RIPPDA 2012 \\
& $\bullet$ & Pengembangan \\
& & Pariwisata \\
& & Pemberdayaan \\
& & masyarakat melalui \\
& & Pariwisata \\
\hline Sumber: Olahan Penulis (2017) & &
\end{tabular}

\section{Teknik Pengolahan Data}

Dalam penelitian ini penulis menggunakan teknik pengolahan data analisis model Miles dan Huberman dalam Sugiyono (2014:91) yaitu data reduction, data display dan conclusion drawing/verification.

1. Reduksi Data (Data Reduction)

Menurut Sugiyono (2014:92) reduksi data adalah merangkum, memilih hal-hal yang pokok, memfokuskan pada hal-hal yang penting, dicari tema dan polanya. Data yang diperoleh kemudian dirangkum untuk dipilih data yang lebih mendalam dan fokus kepada hal yang sesuai dengan data yang dituju yaitu tentang Pemberdayaan Masyarakat di Wisata Edukasi Imah Noong. Data yang direduksi akan memberikan gambaran yang jelas dan mempermudah penulis untuk melakukan pengumpulan dan perumusan data.

2. Sajian Data (Data Display)

Menurut Sugiyono (2014:95) penyajian data bisa dilakukan dalam bentuk uraian singkat, bagan, hubungan antar kategori, flowchart dan metode teks yang bersifat naratif. Penyusunan informasi memberikan data akurat untuk dilakukan penarikan kesimpulan dan tindakan yang hasilnya bersifat deskriptif.

3. Kesimpulan (Conclusion

Drawing/Verification)

Langkah terakhir dengan teknik analisis model Miles dan Huberman adalah penarikan kesimpulan dan verifikasi. Kesimpulan merupakan hasil dari proses reduksi data hingga data tersebut disajikan yang merupakan jawaban atas rumusan masalah yang diteliti, kemudian dapat diambil kesimpulan dari penelitian ini.

\section{HASIL DAN PEMBAHASAN}

A. Gambaran Umum

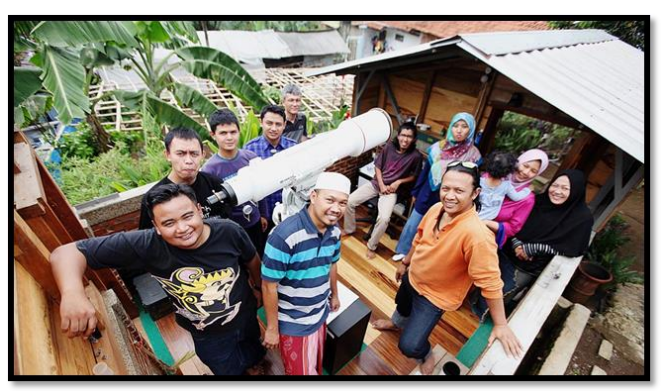

GAMBAR 1. OBSERVATORIUM IMAH NOONG

Imah Noong merupakan sebuah observatorium astronomi dan planetarium pribadi dengan mengusung konsep wisata edukasi. Terletak di Kampung Areng Jalan Areng No.31 RT.02 RW.12 dengan luas sebesar $812 \mathrm{~m} 2$. Kampung Areng ini merupakan salah satu Kampung atau Dusun dari 3 Dusun yang berada pada daerah otonomi Desa Wangunsari. Desa Wangunsari terletak di Kecamatan Lembang Kabupaten Bandung Barat Provinsi Jawa Barat dan memiliki luas wilayah sebesar 380 Ha dengan jumlah penduduk 11.097 jiwa.

Visi Imah Noong:

Pusat sarana eduwisata yang menyatu dengan masyarakat menuju kampung yang berkualitas, ramah lingkungan, berbudaya, maju, dan mandiri.

\section{Misi Imah Noong:}

1. Pemberdayaan masyarakat melalui eduwisata

2. Peningkatan minat belajar melalui program pendidikan kreatif

3. Melestarikan seni dan budaya tradisional

4. Meningkatkan sumber daya manusia dan sumber daya alam lebih maju

Imah Noong ini memiliki keunikan ketika atap Imah tersebut dapat digeser sehingga bagian dalam Imah Noong yang berisi teleskop Bresser yang dapat digunakan untuk melihat berbagai benda langit baik di siang hari maupun di malam hari. Selain kegiatan pengamatan benda langit Imah Noong menawarkan kegiatan lain dengan memanfaatkan kearifan lokal setempat yang melibatkan petani dan peternak di sekitar Kampung Areng dalam kegiatan eduwisata. Kata Imah Noong ini diambil dari Bahasa Sunda karena dimaksudkan untuk mengangkat budaya sunda, Imah yang berarti rumah, sedangkan noong yang berarti mengintip atau melihat. Maka secara harfiah kata Imah Noong memiliki arti sebagai rumah tempat "mengintip" berbagai benda langit dengan fasilitas teleskop yang tersedia. 
Pembangunan observatorium Imah Noong ini dilakukan secara bertahap. Yang dimulai pada tahun 2012 hingga akhir tahun 2014 persis di pekarangan belakang rumah milik Bapak Hendro Setyanto. Kemudian pembangunan tersebut dilanjutkan dengan menambahkan fasilitas utama yaitu Masjid Planetarium. Masjid yang berfungsi sebagai planetarium tempat pemutaran film tentang pengetahuan luar angkasa sekaligus tempat ibadah yang dapat menampung hingga 40 orang yang digunakan setiap saat bagi para wisatawan yang berkunjung ke Imah Noong.

Seiring dengan semakin banyaknya pengunjung yang berkunjung ke area Kampung Areng dengan kehadiran Imah Noong ini, Bapak Hendro berkeinginan membuat konsep pariwisata berbasis edukasi yang melibatkan kawasan sekitar Imah Noong. Pak Hendro kemudian mengajak para petani pembibitan sayuran, peternak kelinci dan peternak sapi perah yang diharapkan dapat membantu pengembangan perekonomian dan pendidikan khususnya untuk Kampung Areng, Desa Wangunsari Lembang Kabupaten Bandung Barat.

Tabel 4. Data Pengelola IMah Noong

\begin{tabular}{|c|c|c|c|}
\hline No & Nama & Keterangan & $\begin{array}{c}\text { Tingkat } \\
\text { Pendidikan }\end{array}$ \\
\hline 1 & $\begin{array}{l}\text { Hendro } \\
\text { Setyanto }\end{array}$ & Pendiri & Strata II \\
\hline 2 & $\begin{array}{c}\text { Irfan } \\
\text { Kristiyanto }\end{array}$ & Pendiri & Strata I \\
\hline 3 & Fahri Ahmad & Pengelola & Strata II \\
\hline 4 & $\begin{array}{c}\text { Arman } \\
\text { Abdurrahman }\end{array}$ & Pengelola & Strata I \\
\hline 5 & Hanik Amelia & Pengelola & Strata I \\
\hline 6 & $\begin{array}{c}\text { Azifah } \\
\text { Anamaliah }\end{array}$ & & Strata I \\
\hline 7 & Diah Titari & $\begin{array}{c}\text { Staff } \\
\text { Pengajar }\end{array}$ & Strata II \\
\hline 8 & Eva Cintawati & Staff & SMA \\
\hline
\end{tabular}

TABEL 5. JUMLAH KunJUNGAN WisATAWAN IMAH NOONG

\begin{tabular}{cc}
\hline Tahun & Jumlah Kunjungan \\
\hline 2015 & 2.048 orang \\
2016 & 569 orang \\
2017 (Hingga Bulan & 248 orang \\
Mei) & \\
Sumber: Pengelola Imah Noong (2017) &
\end{tabular}

B. Pembahasan Pemberdayaan Masyarakat di Wisata Edukasi Imah Noong

Setelah data yang diperoleh selesai diteliti oleh penulis, maka langkah selanjutnya adalah membandingkan temuan tersebut dengan teori yang penulis gunakan. Menurut Sunaryo (2013:221) apabila dilihat dari aspek dimensi pemberdayaan masyarakat melalui sebuah daya tarik wisata kerangka pemberdayaan masyarakat melalui pembangunan kepariwisataan, sasaran-sasaran tersebut harus bermuara pada tiga aspek sebagai berikut:
1. Penguatan kapasitas dan peranan masyarakat

Dengan hadirnya wisata edukasi Imah Noong tentunya telah membawa dampak positif bagi masyarakat sekitar wisata edukasi Imah Noong, khususnya bagi masyarakat Kampung Areng. Berdasarkan hasil observasi langsung ke lapangan dan wawancara dengan Ketua RT.02 dan Ketua Karang Taruna RW.12 didapatkan bahwa sebenarnya pihak pengelola Imah Noong selalu mengajak dan mendorong para masyarakat sekitar untuk turut berperan serta dalam setiap kegiatan. Peranan masyarakat ini yang juga menjadi misi utama Imah Noong dan diharapkan masyarakat Kampung Areng bisa aktif dalam pembangunan dan pengembangan wisata edukasi Imah Noong.

Dalam Undang - Undang Nomor 10 Tahun 2009 tentang Kepariwisataan yang disebutkan dalam Pasal 26, bahwa setiap pengusaha pariwisata berkewajiban untuk berperan aktif dalam upaya pengembangan prasarana dan program pemberdayaan masyarakat. Dalam hal ini pihak pengelola Imah Noong semestinya turut serta membangun kekuatan dan peranan masyarakat untuk ikut mengembangkan daya tarik wisata Imah Noong.

Menurut Sunaryo (2013:223) terdapat beberapa aspek yang perlu diperhatikan oleh para pelaku pembangunan kepariwisataan dalam penguatan kapasitas dan peran masyarakat, yaitu:

\section{1) Pengembangan Kelembagaan masyarakat}

Hal ini berhubungan dengan kemampuan dan keterampilan yang dimiliki oleh masyarakat setempat dalam hal pengetahuan berorganisasi dan keahlian dalam hal pengelolaan dan pengembangan organisasi.

\section{2) Pelibatan peran masyarakat}

Sebagai contoh, dalam hal penguatan kapasitas dan peran masyarakat untuk menjadi pemandu wisata melalui pelatihan dan penyuluhan yang ada agar para wisatawan yang datang bisa dipandu dan dilayani sesuai dengan standar yang ada. Pelatihan dan penyuluhan ini dimaksudkan untuk memberikan peran dan inisiatif masyarakat sekitar wisata edukasi Imah Noong. Namun dari hasil observasi hingga saat ini tidak ada satupun dari masyarakat sekitar yang tertarik untuk menjadi pemandu wisata.

Didapatkan hasil bahwa sebenarnya pihak pengelola Imah Noong telah mengajak dan merangkul masyarakat sekitar terlibat dalam proses penguatan kapasitas dan peranan 
masyarakat dalam mengembangkan Wisata Edukasi Imah Noong. Hal tersebut tercermin dari dengan ajakan dan himbauan bagi masyarakat yang memiliki skill atau pengetahuan lebih di bidang tertentu untuk ikut serta dalam setiap kegiatan dan diharapkan bisa menjadi nilai lebih untuk suatu daya tarik wisata. Hasilnya tanggapan para petani pembibitan sayur, peternak kelinci dan peternak sapi perah cukup positif. Mereka menilai kerja sama yang dilakukan dengan Imah Noong berdampak baik bagi kesejahteraan mereka. Selain itu berbagai kegiatan yang diadakan Imah Noong sesuai dengan salah satu misinya, yakni melestarikan seni dan budaya tradisional lokal serta mempererat silaturahmi dengan masyarakat rutin dilaksanakan setiap tahunnya sejak Imah Noong berdiri.

Pihak pengelola Imah Noong selalu berperan aktif dalam penguatan kapasitas masyarakat sekitar. Hal tersebut tercermin dari program Pendidikan Anak Usia Dini, pendidikan bahasa inggris, pendidikan komputer dan pendidikan agama Islam yang dijalankan oleh pengelola Imah Noong. Imah Noong memberikan program yang bertujuan meningkatkan kapasitas masyarakat dalam kegiatan pemberdayaan masyarakat yang berkaitan dengan pendidikan. Program pendidikan ini bernama Program Desa Dampingan yang menggandeng kerja sama dengan Ikatan Alumni tahun 93 Institut Teknologi Bandung. Program ini ditujukan kepada mereka yang masih duduk di bangku sekolah berupa beasiswa bagi mereka siswa/siswi Sekolah Dasar, Sekolah Menengah Pertama dan Sekolah Menengah Atas/Kejuruan yang berasal dari sekitar Imah Noong khususnya Kampung Areng.

Tentunya hal tersebut dilakukan agar kualitas sumber daya manusia khususnya anakanak yang tinggal di sekitar Kampung Areng dapat lebih ditingkatkan lagi. Pihak pengelola Imah Noong selalu membuka pintu bagi para anak-anak dan remaja di Kampung Areng untuk datang dan belajar bersama serta menyediakan beasiswa yang diharapkan dapat sedikit membantu meringankan beban ekonomi bagi keluarga yang membutuhkan. Terlebih lagi pihak Imah Noong selalu mendapatkan bantuan dari berbagai pihak untuk menyelenggarakan program pendidikan.

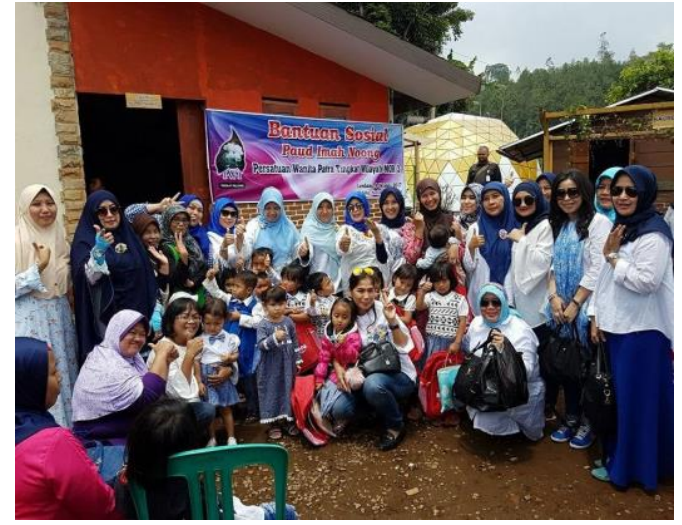

GAMBAR 2. PROGRAM BANTUAN UNTUK PAUD IMAH NOONG

Tentunya program pendidikan untuk penguatan kapasitas dan menumbuhkan peran masyarakat yang dilakukan oleh pihak pengelola Imah Noong sudah sejalan dengan tujuan pemberdayaan masyarakat seperti yang diungkapkan oleh Mardikanto (2015:111) yaitu bahwa salah satu tujuan utama pemberdayaan masyarakat adalah perbaikan pendidikan (better education). Dalam artian bahwa pemberdayaan harus dirancang sebagai suatu bentuk pendidikan yang lebih baik guna mewujudkan perbaikan aksesibilitas (better accessibility) serta perbaikan kehidupan (better living) masyarakat sekitarnya. Hasilnya sebagian besar masyarakat sudah cukup puas dengan program pendidikan dan pemberian beasiswa yang dilakukan oleh Imah Noong. Namun masih ada orang yang tidak bertanggung jawab dengan memanfaatkan beasiswa yang diperoleh untuk digunakan hal yang tidak sesuai dengan peruntukannya, padahal di lain pihak masih banyak keluarga di sekitar Desa Wangunsari khusunya Kampung Areng yang lebih membutuhkan bantuan tersebut.

2. Penguatan akses dan kesempatan berusaha masyarakat

Berdasarkan Undang-Undang Nomor 10 Tahun 2009 tentang Kepariwisataan disebutkan dalam Pasal 4 huruf a, b, c dan d bahwa kepariwisataan bertujuan untuk meningkatkan pertumbuhan ekonomi, meningkatkan kesejahteraan rakyat, menghapus kemiskinan, dan mengatasi pengangguran. Hal ini dipertegas dengan Peraturan Daerah Kabupaten Bandung Barat Nomor 7 Tahun 2013 tentang Penyelenggaraan Kepariwisataan Daerah Pasal 3 huruf a, b dan c, yang menyatakan bahwa penyelenggaraan kepariwisataan bertujuan untuk meningkatkan pertumbuhan ekonomi Daerah, meningkatkan kesejahteraan masyarakat, serta memperluas dan memeratakan kesempatan berusaha dan lapangan kerja. 
Sejalan Peraturan Daerah Kabupaten Bandung Barat tersebut, Pihak Imah Noong sudah melakukan jemput bola dalam hal penguatan akses dan kesempatan berusaha masyarakat sekitar. Hal ini tercermin dari pihak pengelola Imah Noong sudah berkoordinasi dengan Karang Taruna RW 12, pihak RW 11 dan RW 12 serta merangkul para pemangku kepentingan di Kampung Areng untuk mencari dan mengajak masyarakat yang memiliki berbagai keterampilan atau produk yang siap dijual untuk diikutsertakan dalam penjualan di Wisata Edukasi Imah Noong. Produk tersebut nantinya bisa dijual sebagai souvenir yang bisa ditawarkan kepada para pengunjung yang datang ke Imah Noong. Hasilnya sudah ada beberapa masyarakat yang ikut berpartisipasi dalam program tersebut. Beberapa produk di antaranya kaos, pensil benih, sticker, gantungan kunci, dan sebagainya.

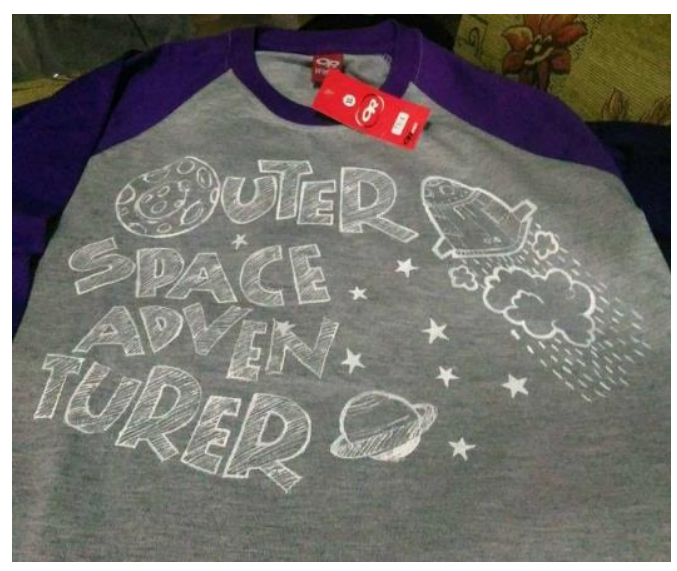

SUMBER: PENGELOLA IMAH NOONG (2017)

\section{GAMBAR 3. SOUVENIR KaOS IMAH NOONG}

Pihak pengelola Imah Noong bekerja sama dengan para petani pembibitan sayur, peternak kelinci, dan peternakan sapi perah untuk ikut menjual hasil produk mereka langsung ke wisatawan yang datang berkunjung. Sebagai contoh, program kerja sama Imah Noong dengan peternak kelinci dimana wisatawan yang datang bisa langsung datang berkunjung ke peternakan kelinci karena termasuk paket wisata edukasi Imah Noong. Kemudian sang peternak kelinci ini bisa langsung menjual kelinci ternak mereka kepada wisatawan tersebut. Tentunya hal ini disambut baik oleh para petani dan peternak di Kampung Areng. Mereka berharap kerja sama ini dapat terus berlanjut karena dapat memberikan keuntungan bagi para petani dan peternak selain dari kegiatan utama mereka.

Pihak pengelola Imah Noong juga telah memberikan kesempatan kepada para masyarakat yang memiliki rumah ataupun kamar agar dapat digunakan sebagai rumah singgah para wisatawan yang datang ke Imah Noong. Rumah singgah (homestay) dibuatkan paket wisata sehingga dapat menambah pemasukan juga bagi masyarakat sekitar. Akan tetapi kurangnya penyuluhan mengenai kualitas minimum dari rumah singgah dan penyuluhan tentang pelayanan kualitas rumah singgah nantinya berdampak pada kepuasan dari wisatawan yang berkunjung. Belum lagi ketakutan masyarakat sekitar yang berkaca pada tingkat kunjungan wisatawan yang berkunjung ke Imah Noong dirasa masih kurang apabila mereka sengaja membuat/membangun sebuah rumah singgah yang lebih bagus.

Sudah ada program yang direncanakan oleh pengelola Imah Noong. Program tersebut berupa warung/toko kecil di Imah Noong yang ditujukan bagi para masyarakat yang ingin berdagang/berjualan di sekitar area Imah Noong. Program berdagang/berjualan ini dapat ditawarkan kepada wisatawan yang datang berkunjung ke Imah Noong. Sayangnya program ini belum bisa terlaksana karena masyarakat sekitar masih terkesan takut dan setengah hati. Hal tersebut disebabkan karena belum stabilnya tingkat kunjungan wisatawan yang datang ke Imah Noong. Selain itu faktor modal dan perizinan dari pihak Pemerintah khususnya Desa yang masih belum turut serta dalam pelaksanaan Wisata Edukasi Imah Noong ini.

\section{Penguatan sadar wisata}

Sunaryo (2013:227) menjelaskan bahwa salah satu aspek penting dan mendasar bagi keberhasilan pengembangan kepariwisataan adalah dapat diciptakannya iklim kondusif bagi tumbuh dan berkembangnya kegiatan kepariwisataan di suatu destinasi. Iklim kondusif tersebut khususnya terkait dengan dukungan, penerimaan dan partisipasi masyarakat terhadap pengembangan pariwisata yang berada di wilayah destinasi tersebut atau yang telah dikenal sebagai konsep sadar wisata. Konsep sadar wisata ini memiliki dua sasaran utama, yaitu:

1) Mendorong masyarakat untuk dapat menciptakan iklim yang kondusif bagi tumbuh dan berkembangnya kegiatan kepariwisataan yang berada di wilayahnya (masyarakat sebagai host atau tuan rumah yang baik)

2) Mendorong masyarakat untuk dapat menjadi pelaku dan pekerja di sektor kepariwisataan yang ada diwilayahnya, baik secara langsung maupun tidak langsung serta mendorong masyarakat itu sendiri menjadi wisatawan atau pihak yang melakukan 
perjalanan wisata ke suatu destinasi wisata yang lain (masyarakat sebagai guest/wisatawan), khususnya dalam lingkup wilayah Nusantara.

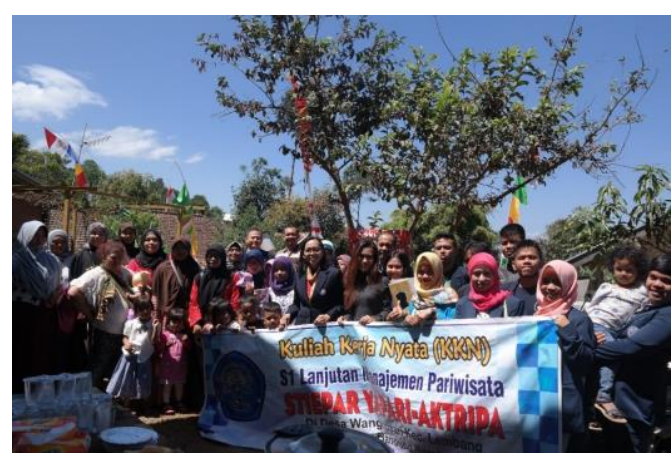

SUMBER: DOKUMENTASI PENULIS (2017)

Gambar 4. PEnyUluhan SAPtA PESONA

Lebih lanjut dijelaskan bahwa partisipasi dan dukungan masyarakat merupakan aspek penting agar berperan sebagai tuan rumah (host) dan memahami serta bersedia untuk mewujudkan SAPTA PESONA di lingkungannya. Sapta Pesona merupakan jabaran konsep "Sadar Wisata" yang terkait dengan lingkungan dan suasana kondusif mampu mendorong tumbuh dan berkembangnya industri pariwisata, melalui perwujudan unsur aman, tertib, bersih, sejuk, indah, ramah, kenangan.

Dalam prakteknya, masyarakat masih belum memahami arti dan manfaat dari konsep Sadar Wisata. Masyarakat Kampung Areng masih belum bisa memahami bagaimana arti penting dari hadirnya daya tarik wisata di lingkungan mereka. Sementara disisi pihak pengelola secara perlahan mencoba memberikan penyuluhan dan pemahaman tentang pentingnya peran masyarakat dalam membangun suasana kondusif untuk kemajuan daya tarik wisata Imah Noong sebagaimana tujuan dari penguatan sadar wisata ini adalah untuk mendorong masyarakat dengan perbaikan lingkungan dan perbaikan masyarakat melalui pembangunan kepariwisataan berbasis masyarakat menuju arah yang lebih baik.

Pihak pengelola Imah Noong memiliki niatan mengajak masyarakat sekitar untuk berperan sebagai wisatawan. Salah satu cara dengan mengajak masyarakat mengunjungi suatu daya tarik wisata lain. Hal tersebut bertujuan memberikan masyarakat sekitar pengalaman dalam berwisata sehingga diharapkan nanti masyarakat bisa memberikan pelayanan serupa dan memberikan dampak positif bagi para wisatawan yang datang ke wisata edukasi Imah Noong. Sayangnya kegiatan ini belum bisa dilaksanakan mengingat belum banyaknya masyarakat yang tertarik untuk bersama-sama secara sukarela untuk membangun daya tarik wisata.

\section{Kesimpulan}

Melalui kegiatan Pemberdayaan Masyarakat dengan adanya Wisata Edukasi Imah Noong diharapkan dapat meningkatkan nilai manfaat positif pembangunan kepariwisataan bagi kesejahteraan ekonomi masyarakat di Kampung Areng Desa Wangunsari Kecamatan Lembang.

Sesuai yang diuraikan oleh Sunaryo (2013:221) kerangka pemberdayaan masyarakat melalui pembangunan kepariwisataan, sasaransasaran tersebut harus bermuara pada tiga aspek sebagai berikut:

\section{Penguatan kapasitas dan peranan masyarakat}

Menurut Sunaryo (2013:223) terdapat beberapa aspek yang perlu diperhatikan oleh para pelaku pembangunan kepariwisataan dalam penguatan kapasitas dan peran masyarakat, yaitu:

a. Pengembangan Kelembagaan masyarakat

Pengembangan kelembagaan yang dilakukan oleh Imah Noong sebenarnya sudah dilakukan dengan semaksimal mungkin dengan melibatkan berbagai pihak, seperti Ibu-ibu Pemberdayaan Kesejahteraan Keluarga (PKK) dan Karang Taruna RW.12. Namun sayangnya belum ada timbal balik dari masyarakat dikarenakan belum adanya izin dan pembicaraan resmi terkait pendirian wisata edukasi Imah Noong dengan pihak Desa Wangunsari, sehingga masyarakat masih terkesan ragu dan takut untuk ikut serta dalam pembangunan dan pengembangan Imah Noong.

b. Pelibatan peran masyarakat

Dalam rangka pelibatan peran masyarakat sebagai pelaku penting dari pembangunan kepariwisataan, pihak Imah Noong sebenarnya sudah membuat beberapa program, yaitu program kerja sama dengan petani dan peternak setempat, program pelatihan pemandu wisata, program pendidikan bahasa dan program bantuan beasiswa bagi yang membutuhkan. Sayangnya masyarakat masih belum sepenuhnya menggunakan kesempatan dari berbagai program yang diberikan oleh Imah Noong. Tercatat dari hasil observasi, hanya program kerja sama Imah Noong dengan peternak dan petani saja yang sudah berjalan dan mendapat respon positif dari masyarakat sekitar.

Selain itu sebagai mana dijelaskan oleh Mardikanto (2015:111) bahwa salah satu tujuan utama pemberdayaan masyarakat adalah perbaikan pendidikan (better education). Dalam artian bahwa pemberdayaan harus dirancang 
sebagai suatu bentuk pendidikan yang lebih baik guna mewujudkan perbaikan aksesibilitas (better accessibility) serta perbaikan kehidupan (better living) masyarakat sekitarnya. Hasilnya sebagian besar masyarakat di Kampung Areng sudah cukup puas dengan program pendidikan dan pemberian beasiswa yang dilakukan oleh Imah Noong. Hal ini membuktikan bahwa program pendidikan dan pemberian beasiswa ini sudah cukup dirasakan manfaatnya dan berhasil mencapai tujuan dari pemberdayaan masyarakat melalui perbaikan pendidikan.

2. Penguatan akses dan kesempatan berusaha masyarakat

Untuk memperkuat akses dan kesempatan berusaha masyarakat, pihak pengelola Imah Noong membuat program kerja sama dengan masyarakat sekitar Kampung Areng yang memiliki keterampilan atau usaha mandiri untuk membuat souvenir, kaos, kerajinan tangan, pensil benih, jam dinding. Gantungan kunci, dll. Hingga saat ini program tersebut sudah cukup berjalan dengan baik dan dirasa cukup membantu perekonomian bagi masyarakat sekitar.

Selain itu pihak pengelola Imah Noong juga membuat program bagi para masyarakat sekitar yang memiliki rumah atau kamar lebih untuk disewakan menjadi homestay. Sayangnya kualitas homestay yang disediakan masyarakat masih kurang memadai menurut pihak pengelola Imah Noong, padahal mereka sudah berusaha untuk melakukan penyuluhan dan pemahaman tentang kualitas rumah singgah yang baik.

Terakhir adalah program kerja sama dengan masyarakat sekitar untuk berdagang di area Imah Noong. Program ini masih belum bisa terlaksana karena jumlah kunjungan wisatawan yang menurut masyarakat sekitar dirasa masih sedikit dibandingkan dengan daya tarik wisata lainnya dan belum adanya izin dari pihak pemerintah khususnya Desa Wangunsari.

\section{Penguatan Sadar Wisata}

Program penyuluhan yang dilakukan oleh Imah Noong dalam usaha menguatkan kesadaran masyarakat akan pentingnya pembangunan kepariwisataan masih belum bisa dirasakan manfaatnya. Padahal pihak pengelola sudah 2 kali mengajak masyarakat mengikuti kegiatan penyuluhan sapta pesona yang dilakukan bersama Sekolah Tinggi Ilmu Ekonomi Pariwisata Bandung. Masyarakat masih kurang memahami arti penting adanya sebuah daya tarik wisata yang bisa menumbuhkan tingkat ekonomi dan kesejahteraan masyarakat.

\section{DAFTAR RUJUKAN}

Anwas, Oos M. (2013). Pemberdayaan Masyarakat di Era Global. Bandung: PT. Alfabeta

Ardika, I W. (2007). Pusaka Budaya \& Pariwisata. Denpasar: Pustaka Larasan

Creswell, John W. (2009). Research Design Qualitative, Quantitative, and Mixed Methods Approaches. California: Sage Publications

Hikmat, H. (2013). Strategi Pemberdayaan Masyarakat. Bandung: Humaniora Utama Press

Hadiwijoyo, S.S. (2012). Perencanaan Pariwisata Pedesaan Berbasis Masyarakat. Yogyakarta: Graha Ilmu

Ismayanti. (2010). Pengantar Pariwisata. Jakarta: Kompas Gramedia

Mardikanto, T. \& Soebiato, P. (2015). Pemberdayaan Masyarakat Dalam Perspektif Kebijakan Publik. Bandung: PT. Alfabeta

Ritchie, J,R. (2003). Aspect of Tourism : Managing Educational Tourism. United Kingdom: Channel View Publication

Ritchie, J.R. Brent \& Goeldner, Charles R. (2009). Tourism:Principles, Practices, Philosophies. New Jersey: Wiley

Sedarmayanti. (2014). Membangun dan Mengembangkan Kebudayaan dan Industri Pariwisata. Bandung: PT. Refika Aditama

Simanjuntak, B.A., Tanjung F. \& Nasution R. (2015). Sejarah Pariwisata Menuju Perkembangan Pariwisata Indonesia. Jakarta: Pustaka Obor

Sugiyono. (2011). Metode Penelitian Administrasi. Bandung: Alfabeta

(2014). Memahami Penelitian Kualitatif. Bandung: Alfabeta

(2016). Metode Penelitian Kuantitatif, Kualitatif, dan R\&D. Bandung: Alfabeta

Suharto, E. (1997). Pembangunan, Kebijakan Sosial dan Pekerjaan Sosial: Spektrum Pemikiran, Bandung: Lembaga Studi Pembangunan - STKS

(2014). Membangun Masyarakat Memberdayakan Rakyat. Bandung: PT. Refika Aditama

Sulaiman, S. \& Kusherdyana. (2012). Statistika Pariwisata. Bandung: PT. Alfabeta 
Sunaryo, B. (2013). Kebijakan Pembangunan Destinasi Pariwisata : Konsep dan Aplikasinya di Indonesia. Yogyakarta: Gava Media

Suroso, R. (2004). Material dan Metode Edukasi dari Perspektif Sains Kognitif. Bandung: Fe Institute

Utama, I.G.B.R \& Mahadewi, N.M.E. (2012). Metodologi Penelitian Pariwisata dan Perhotelan. Yogyakarta: Andi.

Yoeti, O.A. (2016). Pariwisata Budaya: Masalah dan Solusinya. Jakarta: PT. Balai Pustaka (Persero)

(2016). Perencanaan dan Pengembangan Pariwisata. Jakarta: PT. Balai Pustaka (Persero)

Lain-Lain

Laporan Anggaran Pendapatan dan Belanja Desa Wangunsari 2017
Pedoman Kelompok Sadar Wisata. Kementerian Pariwisata dan Ekonomi Kreatif 2012

Peraturan Daerah Kabupaten Bandung Barat Nomor 7 Tahun 2013. Tentang Penyelenggaraan Kepariwisataan Daerah

Peraturan Menteri Desa Nomor 19 Tahun 2017. Tentang Penetapan Prioritas Penggunaan Dana Desa Tahun 2018

Statistik Desa Wangunsari 2017

Undang-Undang Republik Indonesia Nomor 10 Tahun 2009. Tentang Kepariwisataan. 